\title{
PENGARUH MANAJEMEN KELAS TERHADAP KEAKTIFAN BELAJAR PESERTA DIDIK PADA MTS MADANI ALAUDDIN KABUPATEN GOWA
}

\author{
Rosdiana ${ }^{1}$, Nuryamin ${ }^{2}$, Mahammad Rusydi Rasyid ${ }^{3}$, Ahmad Afiif ${ }^{4}$ \\ 1,2,3,4Fakultas Tarbiyah dan Keguruan UIN Alauddin Makassar \\ 1,2,3,4Kampus II: Jalan H. M Yasin Limpo No. 36 Samata-Gowa \\ Email: rosdiana12@gmail.com ${ }^{1}$, nuryaminym@gmail.com², \\ muhammad.rusydi@uin-alauddin.ac.id ${ }^{3}$, ahmad.afiif@uin-alauddin.ac.id ${ }^{4}$
}

\begin{abstract}
Abstrak:
Penelitian ini bertujuan untuk mengetahui pengaruh menajemen kelas terhadap keaktifan peserta didik di MTs Madani Alauddin Kabupaten Gowa. Jenis penelitian ini adalah penelitian kuantitatif dengan pendekatan penelitian yang digunakan adalah Ex Post Facto. Populasi dalam penelitian ini adalah seluruh peserta didik di MTs Madani Alauddin Kabupaten Gowa dengan jumlah 337 peserta didik dan sampel penelitian yang berjumlah 84 peserta didik. Instrumen yang digunakan dalam penelitian ini adalah angket untuk manajemen kelas dan skala untuk keaktifan belajar. Teknik analisis data yang digunakan ialah statistik deskriptif dan teknik analisis inferensial dengan regresi sederhana. Berdasarkan teknik analisis data statistik deskriptif, manajemen kelas di MTs Madani Alauddin Kabupaten Gowa berada pada kategori sedang dan keaktifan belajar peserta didik di MTs Madani Alauddin Kabupaten Gowa berada pada kategori sedang. Sedangkan hasil analisis statistik inferensial menunjukkan nilai t hitung sebesar 3,250 lebih besar dari pada nilai $t$ tabel distribusi dengan nilai 1,980 dengan taraf signifikansi sebesar $5 \%(3,250>1,980)=($ thitung $>$ ttabel $)$ berarti ada pengaruh manajemen kelas terhadap keaktifan belajar peserta didik di MTs Madani Alauddin Kabupaten Gowa.
\end{abstract}

\begin{abstract}
:
This study aims to determine the influence of class management on the learner activity in MTs Madani Alauddin Gowa. This research was quantitative research and the approach was Ex Post Facto. The population in this study were all students in MTs Madani Alauddin with 337 learners and the sample of research which amounted to 84 students. The instrument used in this study was a questionnaire for classroom management and scales for learning activity. Data analysis techniques used were descriptive statistics and inferential analysis techniques with simple regression. Based on descriptive statistical analysis, class management at MTs Madani Alauddin Gowa Regency was in the medium category and the learning activity of learners in MTs Madani Alauddin Gowa Regency was in the medium category. While the results of inferential statistical analysis showed the value of $t$ arithmetic of 3.250 is greater than the value of $t$ distribution table with the value of 1.980 with a significance level of $5 \%(3.250>1.980)=(t$ count $>t$ table) means there is influence of classroom management on the learning activities of learners in MTs Madani Alauddin Kabupaten Gowa.
\end{abstract}

Kata kunci:

Manajemen Kelas, Keaktifan Belajar

PENDIDIKAN dan manusia tidak dapat terpisahkan, karena manusia merupakan 
subyek dan obyek dari pendidikan itu sendiri. Dalam arti sederhana, pendidikan sering diartikan sebagai usaha manusia untuk membina kepribadiaannya sesuai dengan nilai-nilai dalam suatu masyarakat dan kebudayaan. Dalam perkembangannya istilah pendidikan atau paedagogi berarti bimbingan atau pertolongan yang diberikan dengan sengaja oleh orang dewasa agar ia menjadi dewasa (Hasbullah, 2012).

Menurut Undang-Undang Nomor 20 tahun 2003 tentang Sistem Pendidikan Nasional, pendidikan adalah usaha sadar dan terencana untuk mewujudkan suasana belajar dan proses pembelajaran agar peserta didik secara aktif mengembangkan potensi dirinya untuk memiliki kekuatan spiritual keagamaan, pengendalian diri, kepribadian, kecerdasan, akhlak mulia, serta ketermpilan yang diperlukan dirinya, masyarakat bangsa dan negara (Undang-Undang Republik Indonesia Nomor 20 Tahun 2003 tentang Sistem Pendidikan Nasional).

Lebih lanjut, pendidikan merupakan fenomena manusia yang fundamental, dan berisi sifat konstruktif dalam hidup manusia. Manusia dituntut untuk mampu mengadakan refleksi ilmiah tentang pendidikan tersebut sebagai pertanggungjawaban atas perbuatan yang dilakukan, yaitu mendidik dan dididik. Tindakan atau perbuatan mendidik menuntun anak didik mencapai tujuan-tujuan tertentu, dan hal ini tampak pada perubahan dalam diri anak didik (Hasbullah, 2012).

Berbicara mengenai pencapaian tujuan pendidikan, tidak akan berhasil tanpa adanya peran besar dari seorang pendidik, dalam hal ini guru profesional dan berkualitas. Salah satu unsur penting dalam mengakselerasi kemajuan peserta didik adalah guru. Guru yang care terhadap peserta didiknya, mampu berkomunikasi dengan baik serta dapat menciptakan lingkungan belajar yang kondusif.

Seorang guru harus meyakini bahwa pekerjaannya adalah pekerjaan profesional sehingga semua standar pendidikan berusaha dipenuhinya. Guru mempunyai peran penting unutk mencapai tujuan pembelajaran. Bagaimanapun idealnya suatu kurikulum tanpa ditunjang dengan kemampuan guru untuk mengimplementasikannya, maka kurikulum itu tidak akan bermakna sebagai salah satu instrumen Pendidikan (Getteng, 2014).

Dikemukakan dalam Nomor 14 Tahun 2005 tentang Guru dan Dosen, Guru adalah pendidik profesional dengan tugas utama mendidik, mengajar, membimbing, (ta'lim) mengarahkan, melatih, menilai, dan mengevalusai peserta didik pada pendidikan anak usia dini jalur pendidikan formal, pendidikan dasar, dan pendidikan menengah (Undang-Undang Republik Indonesia Nomor 14 Tahun 2005 tentang Guru dan Dosen). Berdasarkan Undang-Undang tersebut dapat diketahui bahwa tugas seorang guru bukan hanya mengajar dan mendidik tetapi seorang guru merupakan tenaga profesional yang bertanggungjawab megelola proses belajar mengajar di setiap jenjang pendidikan.

Di samping itu, guru mengemban pekerjaan manajemen terutma terkait dengan cara memodifikasi siatuasi kelas sehingga dalam proses pembalajaran tersebut dapat tercipta atmosfil belajar yang baik dan menyenangkan. Untuk itu seorang guru harus memiliki keterampilan dalam menerapkan manajemen kelas. Manajemen kelas bertu- 
juan untuk menciptakan pembelajaran yang aktif, inovatif, kreatif, efektif dan menyenangkan. Oleh karena itu, guru sebagai pendidik harus mampu menerapkan inovasi pembelajaran di dalam kelas termasuk kemampuan dalam mengelola kelasnya dengan baik.

Keaktifan belajar peserta didik merupakan hal yang tak kalah penting dalam meningkatkan mutu belajar. Pada saat peserta didik aktif jasmaninya dengan sendirinya jiwanya akan ikut aktif pula. Peserta didik diharapkan dapat mengekspresikan kemampuannya secara totalitas, maka dari itu peserta didik harus diberi kesempatan untuk berimprovisasis. Mengaktifkan siswa baik dari segi fisik maupun fsikis berarti memberi peluang kepada siswa ubtuk belaja secara hoistik, menggunakan nalar dan rasa, misalnya dapat dilakukan dalam melatih siswa memcahkan maslah, mengambil keputusan, menganalisa sesuati dan seterusanya (Usman, 2009).

Berdasarkan uraian di atas, maka peneliti akan melakukan penelitian tentang Pengaruh Manajemen Kelas terhadap Keaktifan Belajar Peserta Didik pada MTs. Madani Alauddin Kabupten Gowa. Adapun rumusan masalahnya sebagai berikut: Bagaimana gambaran manajemen kelas pada MTs. Madani Alauddin Kabupaten Gowa?, Bagaimana gambaran keaktifan belajar peserta didik pada MTs. Madani Alauddin Kabupaten Gowa?, Adakah pengaruh manajemen kelas terhadap keaktifan belajar peserta didik di MTs. Madani Alauddin Kabupaten Gowa?

\section{KAJIAN PUSTAKA}

\section{Manajemen Kelas}

Arti manajemen menurut bahasa ialah pengelolaan. Manajemen merupakan kata yang berasal dari bahasa Inggris, management. Sedangkan menurut istilah, manajemen merupakan suatu proses penggunaan sumber daya secara efektif untuk mencapai sasaran atau tujuan tertentu (Muhaimin, dkk, 2009). Manajemen menurut Djamarah dengan mengutip Arikunto adalah pengadministrasian, pengaturan atau piñataan suatu kegiatan (Djamarah dan Zain, 2010). Manajemen memiliki beberapa fungsi, yakni; merencanakan, mengorganisasi, melaksanakan, mengontrol dan mengevaluasi. Dalam pendidikan, manajemen itu dapat diartikan sebagai aktivitas memadukan sumber-sumber pendidikan agar terpusat dalam usaha mencapai tujuan pendidikan yang telah ditentukan sebelumnya (Pidarta, 2011).

Kelas dalam Kamus Besar Bahasa Indonesia adalah ruang tempat belajar di sekolah. Adapula yang memandang kelas sebagai sekelompok siswa pada waktu yang sama menerima pelajaran yang sama dari guru yang sama pula. Sedangkan kelas menurut Oemar Hamalik adalah suatu kelompok orang yang melakukan kegiatan belajar bersama, yang mendapat pengajaran dari guru (Djamarah, 2000).

Di samping itu, Djamarah (2000) yang dikutip dari Hadari Nawawi memandang kelas dari dua sudut. Pertama, kelas dalam arti sempit, ruangan yang dibatasi oleh empat dinding, tempat sejumlah siswa berkumpul untuk mengikuti proses belajar mengajar. Kedua, kelas dalam pengertian tradisional yang mengandung sifat statis 
karena sekadar menunjuk pengelompokan siswa menurut tingkat perkembangannya, antara lain berdasarkan pada batas umur kronologis masing-masing.

Kelas dalam arti luas, suatu masyarakat kecil yang merupakan bagian dari masyarakat sekolah, yang sebagai satu kesatuan diorganisasi menjadi unit kerja yang secara dinamis menyelenggarakan kegiatan-kegiatan belajar mengajar yang kreatif untuk mencapai satu tujuan (Djamarah dan Zain, 2010).

Berdasarkan beberapa pendapat di atas, dapat disimpulkan bahwa kelas adalah suatu tempat atau lokasi yang di dalamnya terdapat sekelompok orang yang melakukan proses belajar mengajar untuk mencapai tujuan pendidikan.

Priansa (2015), menyebutkan bahwa manajemen kelas merupakan keterampilan guru untuk menciptakan iklim pembelajaran yang kondusif dan mengendalikannya dalam pembelajaran. Hal itu sejalan dengan pendapat Wiyani (2013) yang mengatakan bahwa manajemen kelas adalah keterampilan guru sebagai seorang leader sekaligus manajer dalam menciptakan iklim kelas yang kondusif untuk meraih kegiatan belajar mengajar.

Danim (2002) dengan mengutip J.M. Cooper, secara rinci merumuskan lima definisi manajemen kelas sesuai dengan konsep modern tentang manajemen kelas, di antaranya:

a. Manajemen kelas dipandang sebagai suatu proses untuk mengendalikan atau mengontrol perilaku siswa di dalam kelas.

b. Manajemen kelas merupakan upaya menciptakan kebebasan bagi diri peserta didik.

c. Manajemen dipandang sebagai suatu proses pemodifikasian perilaku (behavioral modification) peserta didik.

d. Manajemen kelas dipandang sebagai proses menciptakan suasana sosioemosional yang positif di dalam kelas.

e. Manajemen kelas dipandang sebagai upaya pemberdayaan (empowering) sebuah sistem sosial atau proses kelompok (group processes) sebagai intinya.

Berdasarkan beberapa pendapat yang dikemukakan para ahli di atas dapat disimpulkan bahwa manajemen kelas adalah usaha sadar dan terencana yang dilakukan oleh seorang guru atau penanggung jawab untuk merencanakan, mengorganisasikan, melaksanakan/mengaktualisasikan, melakukan pengawasan atau controlling terhadap kegiatan-kegiatan yang dilaksanakan sehingga proses belajar mengajar dapat berlangsung secara efektif dan efisien serta menciptakan kondisi yang kondusif agar segala potensi peserta didik mampu dioptimalkan.

\section{Fungsi dan Tujuan Manajemen Kelas}

Manajemen dalam kelas diklasifikasikan atas dua fungsi utama, yaitu: fungsi organik dan fungsi pelengkap. Fungsi organik terkait dengan semua fungsi yang mutlak dijalankan oleh manajemen organisasi, sedangkan fungsi pelengkap terkait dengan semua fungsi yang mendukung pencapaian kinerja organisasi agar lebih efektif dan efisien (Priansa, 2015). 
Keberhasilan suatu kegiatan dapat dilihat dari hasil yang dicapaianya. Tujuan pengelolaan kelas pada hakikatnya terkandung dalam tujuan pendidikan. Secara umum tujuan manajemen kelas adalah penyediaan fasilitas bagi bermacam-macam kegiatan belajar siswa dalam lingkungan sosial, emosioanal, dan intelektual dalam kelas untuk meningkatkan efektivitas dan efisiensi dalam pencapaian tujuan pembelajaran. Arikunto (dalam Djamarah dan Aswan, 2010) berpendapat bahwa tujuan pengelolaan kelas adalah agar setiap anak di kelas dapat bekerja dengan tertib sehingga segera tercapai tujuan pengajaran secara efektif dan efisien.

Adapun tujuan manajemen kelas secara khusus, dibagi menjadi dua yaitu: tujuan untuk siswa dan tujuan untuk guru.

1. Tujuan untuk Siswa

a. Mendorong siswa untuk mengembangkan tanggung jawab individu terhadap tingkah lakunya dan kebutuhan untuk mengontrol diri sendiri.

b. Membantu siswa untuk mengetahui tingkah laku yang sesuai dengan tata tertib kelas dan memahami bahwa teguran guru merupakan suatu perinhgatan dan bukan kemarahan.

c. Membangkitkan rasa tanggung jawab untuk melibatkan diri dalam tugas maupun pada kegiatan yang diadakan (Djamarah, 2005).

Dapat disimpulkan tujuan manajemen kelas adalah agar setiap anak di kelas dapat bekerja dengan tertib untuk tercapainya tujuan pengajaran secara efektif dan efisien.

2. Tujuan untuk Guru

a. Mengembangkan pemahaman dalam penyajian pe;ajaran dengan pembukaan yang lancar dan kecepatan yang tepat.

b. Menyadari akan kebutuhan siswa dan memiliki kemampuan untuk memberikan petunjuk secara jelas kepada siswa.

c. Mempelajari bagaimana merespon secara efektif terhadap tingkah laku yang mengganggu.

d. Strategi remedial yang lebih komprehensif yang dapat digunakan dalam hubungan dengan masalah tingkah laku siswa yang muncul di dalam kelas.

Berdasarkan uraian di atas dapat disimpulkan bahwa, setiap guru mampu menguasai dan mengontrol kelas maka dianjurkan untuk menggunakan berbagai macam pendekatan dengan menyesuaikan permasalahan yang ada sehingga tercipta suasana kelas yang kondusif, efektif, dan efisien.

\section{Prinsip-prinsip Manajemen Kelas}

Dalam rangka meminimalisir masalah gangguan dalam pengeloaan kelas, maka prinsip-prinsip pengelolaan kelas dapat dipergunakan. Prinsip-prinsip manajemen kelas, terdiri atas:

1. Hangat dan Antusias

Guru yang hangat dan akrab pada peserta didik selalu menunjukkan antusias pada tugasnya atau pada aktivitasnya akan berhasil dalam mengimplementasikan pe- 
ngelolaan kelas. Terdapat beberapa cara yang dapat dilakukakan oleh guru untuk membangunikatan emosional antara guru dengan peserta didik, di antaranya:

a. Tidak segan untuk menyapa peserta didik terlebih dahulu

b. Membiasakan diri untuk berjabat tangan dengan peserta didik

c. Membuka keran komunikasi dengan peserta didik

d. Memperlakukan peserta didik sebagai manusia yang sederajat

2. Tantangan

Penggunaan kata-kata, tindakan, cara kerja, atau bahan-bahan yang menantang akan meningkatkan gairah peserta didik untuk belajar sehingga mengurangi potensi munculnya tingkah laku yang menyimpang. Berikut ini beberapa kegiatan yang dapat dilakukan oleh guru dalam memberikan tantangan kepada peserta didik, antara lain:

a. Melakukan evaluasi sederhana secara berkala setiap minggu

b. Mengaitkan materi pelajaran dengan berbagai fakta di lapangan

c. Mengajarkan keterampilan hidup dalam kegiatan belajar kepada peserta didik (Wiyani, 2013).

\section{Bervariasi}

Penggunaan alat atau media, gaya mengajar guru, pola interaksi anatara guru dan peserta didik akan mengurangi munculnya gangguan, meningkatkan perhatian peserta didik. Kevariasian ini merupakan kunci untuk tercapainya pengelolaan kelas yang efektif dan menghindari kejenuhan.

4. Keluwesan

Keluwesan tingkah laku guru untuk mengubah strategi mengajarnya dapat mencegah kemungkinan munculnya gangguan peserta didik serta menciptakan iklim belajar mengajar yang efektif. Keluwesan pengajaran dapat mencegah munculnya gangguan keributan seperti keributan peserta didik, tidak ada perhatian, tidak mengerjakan tugas dan sebagainya (Priansa, 2015).

5. Penekanan hal yang positif

Guru harus mampu menekankan pada hal-hal yang positif dan menghindari pemusatan perhatian pada hal-hal yang negatif. Penekanan pada hal-hal yang positif yaitu penekanan yang dilakukan guru terhadap tingkah laku peserta didik yang positif, bukan mengomeli tingkah laku yang negatif. Penekanan tersebut dapat dilakukan dengan pemberian penguatan yang positif dan kesadaran guru untuk menghindari kesalahan yang dapat mengganggu jalannya proses belajar mengajar.

6. Penanaman Kedisiplinan

Tujuan akhir dari pengelolaan kelsa adalah peserta didik dapat mengembangkan disiplin diri sendiri dan guru sendiri hendaknya menjadi teladan mengendalikan diri dan pelakksanaan tanggung jawab. Jadi, guru harus disiplin dalam segala hal bila ingin peserta didiknya berdisiplin dalam segala hal pula (Djamarah dan Aswan, 2010). 


\section{Kegiatan Utama dalam Manajemen Kelas}

Kegiatan manajemen kelas meliputi dua kegiatan yang secara garis besar terdiri dari:

1. Pengaturan Peserta Didik

Peserta didik adalah orang yang melakukan kegiatan dan aktivitas di kelas yang ditempatkan sebagai objek dan arena pengembangan ilmu pengetahuan dan kesadaran manusia, maka peserta didik bergerak dan menduduki fungsi sebagai subyek. Artinya, peserta didik bukanlah suatu barang atau objek yang hanya dikenai, melainkan juga merupakan objek yang memiliki potensi dan tujuan untuk bergerak. Pengaturan peserta didik harus dilakukan dengan penuh hati-hati, ketelatenan dan kesabaran yang tinggi. Karena yang akan diatur adalah kondisi emosionalnya, bagaimana peserta didik dalam bertingkah laku, disiplin, memiliki minat dan perhatian, gairah belajar dan dinamika kelompok. Guru berperan mengatur dan menempatkan peserta didik di dalam kelas sesuai dengan potensi intelektual dan perkembangan emosionalnya. Peserta didik diberikan kesempatan untuk memperoleh posisi dalam belajar yang sesuai dengan minat dan keinginannya.

2. Pengaturan Fasilitas

Aktivitas yang dilakukan guru maupun pesertta didik di dalam kelas sangat dipengaruhi oleh kondisi dan situasi fisik lingkungan kelas. Oleh karena itu, lingkungan fisik kelas berupa sarana dan prasarana kelas harus dapat memenuhi dan mendukung interaksi yang terjadi d ruamg kelas (Priansa, 2015). Kondisi fisik kelas yang perlu dilakukan pengaturan agar tercipta lingkungan belajar yang kondusif, yaitu:

a. Ventilasi dan Penataan Cahaya

Ventilasi harus sesuai dengan ruang kelas, kelas bebas dari asap rokok, dan cahaya yang masuk harus cukup.

b. Penataan Keindahan dan Kebersihan Kelas

Pajangan kelas seperti hiasan dinding hendaknya dimanfaatkan untuk kepentingan pengajaran, penempatan lemari harus sesuai dan tertata rapi serta pemeliharaan kebersihan dianjurkan siswa bergiliran untuk membersihkan kelas dan tugas guru memeriksa dan sesekali ikut serta dalam kebersihan kelas.

c. Pengaturan tempat duduk

Tempat duduk mempengaruhi siswa dalam belajar. Untuk itu, pengaturan tempat duduk harus sesuai dengan kegiatan apa yang akan dilakukan, misalanya posisi berhadapan, posisi setengah lingkaran, dan posisi berbaris kebelakang.

\section{Kegiatan Utama dalam Manajemen Kelas}

Keaktifan merupakan kata yang mendapat imbuhan "ke" dan akhiran "an" dari kata dasar aktif. Aktif menurut Kamus Besar Bahasa Indonesia berarti giat (bekerja, berusaha) sedangkan keaktifan berarti kegiatan (kesibukan). Menurut Sardiman (2001), keaktifan adalah kegiatan yang bersifat fisik maupun mental, yaitu berbuat dan berfikir sebagai suatu rangkaian yang tidak dapat dipisahkan. 
Whipple dalam Hamalik (2001) mengemukakan bahwa keaktifan belajar adalah suatu proses belajar mengajar yang menekankan keatifan siswa secara fisik, mental, intelektual dan emosional guna memperoleh hasil belajar berupa perpaduan antara aspek kognitif, afektif dan psikomotor selama siswa berada di dalam kelas. Keaktifan belajar siswa merupakan proses pembelajaran yang mengarah kepada pengoptimalisasian intelektual-emosional siswa dalam proses pembelajaran dengan melibatkan fisik siswa.

Keaktifan yang dialami oleh peserta didik berhubungan dengan segala aktivitas yang terjadi, baik secara fisik maupun non fisik. Keaktifan akan menciptakan situasi belajar yang aktif. Belajar yang aktif adalah suatu suatu sistem belajara mengajar yang menekankan keaktifan peserta didik, baik secara fisik, mental intelektual, maupun emosional guna memperoleh hasil belajar yang berupa perpaduan antara aspek kognitif, afektif dan psikomotor. Belajar yang aktif diperlukan oleh peserta didik untuk mendapatkan hasil belajar yang optimal (Priansa, 2015).

Keaktifan lahir dari aktivitas peserta didik. Dari aktivitas-aktivitas tersebut tingkat keaktifan bisa terdeteksi, mana peserta didik yang bisa dikategorikan aktif dan mana yang pasif. Proses pembelajaran yang dilakukan oleh peserta didik adalah salah satu aktivitas yang bisa memicu keaktifan baik itu aktif dalam mengkaji ilmu pengetahuan, aktif dalam bersikap, dan aktif dalam menciptakan keterampilan-keterampilan dalam diri peserta didik. Belajar yang berhasil harus melalui berbagai macam aktivitas, baik itu aktivitas fisik maupun aktivitas psikis. Aktivitas fisik ialah peserta didik giat aktif dengan anggota badan, membuat sesuatu, bermain maupun bekerja, ia tidak hanya duduk dan mendengarkan, melihat atau hanya pasif. Sedangkan peserta didik yang memiliki aktivitas psikis (kejiwaan) adalah jika daya jiwanya bekerja sebanyak-banyaknya atau banyak berfungsi dalam rangka pembelajaran.

\section{Prinsip-prinsip Keaktifan Belajar}

Menurut W. Gulo (2002), prinsip-prinsip yang perlu diperhatikan dalam usaha menciptakan kondisi belajar dengan aktivitas optimal, sebagai berikut:

\section{Prinsip Motivasi}

Di mana guru berperan sebagai motivator yang merangsang dan membangkitkan motif-motif yang positif dari siswa dalam pembelajarannya. Suatu motif adalah suatu set yang dapat membuat individu melakukan kegiatan-kegiatan tertentu untuk mencapai tujuan.

2. Prinsip Latar atau Konteks

Prinsip konteks yaitu prinsip keterhubungan bahan baru dengan apa yang telah diperoleh siswa sebelumnya.

3. Prinsip Keterarahan

Adanya pola pengajaran yang menghubung-hubungkan seluruh aspek pengajaran. Artinya di sini terdapat satu pola pengajaran yang bisa mengarahkan kepada aspek pengajaran lain atau satu pola pengajaran tersebut mengarahkan kepada berbagai macam aspek pengajaran sehingga rana kognitif siswa bisa terasah dan berpikir aktif. 


\section{Prinsip Belajar Sambil Bekerja}

Prinsip ini berarti mengintegrasikan pengalaman dengan kegiatan fisik dan pengalaman dengan kegiatan intelektual. Jadi, siswa bisa dengan mudah memahami dan merasakan sendiri apa aktivitas yang dilakukannya dan apa manfaat yang didapatkan dari aktivitas tersebut.

\section{Prinsip Perbedaan Perorangan}

Prinsip perbedaan perorangan yaitu kegiatan bahwa ada perbedaan-perbedaan tertentu di dalam diri setiap siswa, sehingga mereka tidak diperlakukan secara klasikal. Guru harus menyadari hal tersebut agar dapat mengimplementasikan metode yang akan diaplikasikan.

6. Prinsip Menemukan

Prinsip ini, yaitu membiarkan atau memberi kebebasan kepada siswa sendiri menemukan informasi yang dibutuhkan dengan pengarahan yang seperlunya dari guru.

7. Prinsip Pemecahan Masalah

Prinsip ini berfungsi mengarahkan siswa untuk peka terhadap masalah dan mempunyai kegiatan untuk mampu menyelesaikannya.

\section{Bentuk-bentuk Keaktifan Belajar}

Hamalik (2001) menyatakan bahwa keaktifan belajar dapat diklasifikasikan ke dalam delapan kelompok, sebagai berikut:

1. Visual, terdiri dari membaca, melihat gambar-gambar, mengamati eksperimen, demonstrasi, pameran, dan mengamati orang lain bekerja atau bermain.

2. Lisan terdiri dari mengemukakan suatu fakta atau prinsip, menghubungkan suatu tujuan, mengajukan suatu pertanyaan, memberi saran, mengemukakan pendapat, wawancara, diskusi, dan interupsi.

3. Mendengarkan terdiri dari mendengarkan penyajuan bahan, mendengarkan percakapan atau diskusi kelompok, mendengarkan suatu permainan, mendengarkan radio.

4. Menulis terdiri dari menulis cerita, menulis laporan, memeriksa karangan, memeriksa bahan-bahan kopi, membuat rangkuman, mengerjakan tes, dan mengisikan angket.

5. Menggambar terdiri dari menggambar, membuat grafik, chart, diagram peta dan pola.

6. Metrik terdiri dari melakukan percobaan, memilih alat-alat, melaksanakan pameran, menari dan berkebun.

7. Mental terdiri dari merenungkan, mengingatkan, memecahkan masalah, menganalisa faktor-faktor, melihat hubungan-hubungan, serta membuat keputusan.

8. Emosional terdiri dari minat, membedakan, berani, tenang dan lain-lain. Kegiatankegiatan dalam kelompok ini terdapat dalam semua jenis kegiatan overlap satu sama lain.

Uraian di atas menunjukkan bahwa banyak aktivitas yang bisa dilakukan peserta didik di sekolah maupun kelas. Untuk mengoptimalkannya, sekolah dan guru ha- 
rus memberikan fasilitas yang memadai baik itu berupa fasilitas fisik maupun non fisik. Perlu keterampilan manajemen dalam melakukan pengaturan tersebut agar proses belajar berjalan seefisien dan seefektif mungkin.

\section{Faktor-faktor yang Memengaruhi Keaktifan Belajar}

Beberapa faktor yang dapat menumbuhkan timbulnya keaktifan peserta didik dalam proses pembelajaran, antara lain:

1. Memberikan motivasi atau menarik perhatian peserta didik, sehingga mereka berperan aktif dalam kegiatan pembelajaran.

2. Menjelaskan tujuan instruksional (kemampuan dasar kepada peserta didik).

3. Mengingatkan kompetensi belajar kepada peserta didik.

4. Memberikan stimulus (masalah, topik, dan konsep yang akan dipelajari).

5. Memberi petunjuk kepada peserta didik cara mempelajari topik yang diberikan.

6. Memunculkan aktivitas, partisipasi peserta didik dalam kegiatan pembelajaran.

7. Memberikan umpan balik (feed back).

8. Melakukan tagihan-tagihan kepada peserta didik berupa tes, sehingga kemampuan peserta didik selalu terpantau dan terukur.

9. Menyimpulkan setiap materi yang disampaikan di akhir pelajaran (Priansa, 2015).

\section{METODE PENELITIAN}

\section{Jenis dan Pendekatan Penelitian}

Untuk memperoleh data-data, fakta, dan informasi yang akan mengungkapkan dan menjelaskan permasalahan, peneliti menggunakan pendekatan kuantitatif. Jenis penelitian yang akan digunakan dalam penelitian ini adalah penelitian ex post facto (causal comperative research) yaitu penelitian empiris yang sistematis di mana ilmuwan tidak mengendalikan variabel secara langsung karena eksistensi dari variabel tersebut telah terjadi, atau karena variabel tersebut pada dasarnya tidak dapat dimanipulasi (Emzir, 2013). Penelitian ini akan berlangsung di MTs. Madani Alauddin Kabupaten Gowa.

Populasi dalam penelitian ini adalah seluruh siswa pada sekolah MTs Madani Alauddin Kabupaten Gowa yang berjumlah 337 peserta didik. Dalam penentuan sampel peneliti menggunakan teknik "random sampling" yaitu pemilihan elemen populasi dilakukan sedemikian rupa sehingga setiap elemen mempunyai kesempatan yang sama untuk terpilih (Supranto, 2008). Sampel penelitian ini berjumlah 84 peserta didik yang diambil $25 \%$ dari jumlah populasi.

\section{Teknik Pengumpulan Data}

Teknik pengumpulan data yang akan digunakan dalam penelitian ini adalah angket (kuesioner). Kuesioner merupakan teknik pengumpulan data yang dilakukan dengan cara memberi perangkat pertanyaan atau pertanyaan tertulis kepada responden untuk dijawabnya (Ismail, 2015). 


\section{Instrumen Penelitian}

Instrumen yang digunakan dalam penelitian ini adalah skala psikologi. Skala merupakan kesepakatan yang digunakan sebagai acuan untuk menentukan panjang pendeknya interval yang ada dalam alat ukur, sehingga alat ukur tersebut bila digunakan dalam pengukuran akan menghasilkan data kuantitatif. Skala yang akan digunakan ialah skala Likert, dimana skala ini digunakan untuk mengukur sikap, pendapat, dan persepsi seseorang atau sekelompok orang tentang fenomena sosial. Dalam penelitian, fenomena sosial ini telah ditetapkan secara spesifik oleh peneliti, yang selanjutnya disebut sebagai variabel penelitian (Sugiyono, 2015).

Angket penerapan manajemen kelas disusun berdasarkan teori Novan Ardy Wiyani dengan aspek: 1) Menciptakan iklim belajar yang tepat, 2) Mengatur ruang belajar, dan 3) Mengelola interaksi belajar mengajar. Skala keaktifan belajar peserta didik disusun berdasarkan teori Donni Juni Priansa dengan aspek: Visual, lisan, mendengarkan, menulis, menggambar, metrik, mental, dan emosional.

Untuk menganalisa data, penulis menggunakan 2 teknik analisis data, yaitu: teknik analisis statistik deskriptif dan teknik teknik analisis statistik inferensial. Adapun langkah-langkah analisis statistik inferensial, sebagai berikut: 1) Analisis regresi sederhana, 2) Uji signifikan, dan 3) Uji hipotesis.

\section{HASIL DAN PEMBAHASAN}

Hasil uji statistik inferensial pengaruh manajemen kelas terhadap keaktifan belajar peserta didik dapat dilihat pada uraian berikut.

\section{Analisis Regresi Sederhana}

$$
\begin{gathered}
\mathrm{Y}=\alpha+b x \\
a=\frac{\left(\sum Y\right)\left(\sum X^{2}\right)-\left(\sum X\right)\left(\sum X Y\right)}{n \sum X^{2}-\left(\sum X\right)^{2}} \\
=\frac{(6581)(555851)-(6778)(533356)}{(84)(555851)-(6778)^{2}} \\
=\frac{3658055431-3615086968}{46691484-45941284} \\
=\frac{42968463}{750200} \\
=57,28
\end{gathered}
$$

Koefisien arah regresi yaitu:

$$
\begin{aligned}
b & =\frac{n \sum X Y-\left(\sum X\right)\left(\sum Y\right)}{n \sum X^{2}-\left(\sum X\right)^{2}} \\
& =\frac{(84)(533356)-(6778)(6581)}{(84)(555851)-(6778)^{2}}
\end{aligned}
$$




$$
\begin{aligned}
= & \frac{44801904-44606018}{46691484-45941284} \\
= & \frac{195886}{750200} \\
& =0,26 \\
\text { Jika } X=84, \text { maka } Y & =57,28+(0,26)(84) \\
& =57,28+21,84 \\
& =79,12
\end{aligned}
$$

\section{Uji Signifikansi (Uji t)}

\section{Regresi, Kesalahan Bakunya Dirumuskan}

$$
\begin{aligned}
\text { Se } & =\sqrt{\frac{\Sigma Y^{2}-(a \Sigma Y)-(b . \Sigma Y X)}{n-2}} \\
& =\sqrt{\frac{520796-(57,28)(6581)-(0,26)(533356)}{84-2}} \\
& =\sqrt{\frac{520796-376959,68-138672,56}{82}} \\
& =\sqrt{\frac{5163,76}{82}} \\
& =\sqrt{62,97}=7,94
\end{aligned}
$$

Regresi b (Penduga b), Kesalahan Baku Akan Dirumuskan:

$$
\begin{aligned}
S_{b} & =\frac{S_{e}}{\sqrt{X^{2}-\frac{(\Sigma X)^{2}}{n}}} \\
& =\frac{7,94}{\sqrt{555851-\frac{(6778)^{2}}{84}}} \\
& =\frac{7,94}{\sqrt{555851-\frac{45941284}{84}}} \\
& =\frac{7,94}{\sqrt{555851-546920,05}} \\
& =\frac{7,94}{\sqrt{8930,95}}
\end{aligned}
$$




$$
=\frac{7,94}{94,50}=0,08
$$

\section{Menguji Hipotesis}

Menentukan Formulasi Hipotesis

Ho $: \beta o \rightarrow \beta o=0$

На $: \beta \neq \beta$ o

Menentukan Taraf nyata $(\alpha)$ dan nilai $t_{\text {tabel }}$

$$
\begin{aligned}
\alpha=5 \% & =0,05 \rightarrow \alpha / 2=0,025 \\
\mathrm{dk} 2 & =\mathrm{n}-2 \\
& =84-2 \\
& =82 \\
\mathrm{t}_{\text {tabel }} & =\mathrm{t} 0,025(82)=1,980
\end{aligned}
$$

Menentukan nilai uji statistik

$$
\begin{aligned}
t & =\frac{b}{S b} \\
& =\frac{0,26}{0,08} \\
& =3,250
\end{aligned}
$$

Karena thitung $=3,250>\mathrm{t} 0,025(82)=1,980$, maka H0 ditolak. Berdasarkan hasil tersebut, dapat disimpulkan bahwa manajemen kelas berpengaruh terhadap keaktifan belajar peserta didik di MTs Madani Alauddin Kabupaten Gowa.

Berdasarkan hasil statistik inferensial pengujian hipotesis yang menunjukkan bahwa nilai $(t)$ yang diperoleh dari hasil perhitungan $\left(t_{\text {hitung }}\right)=3,250$ lebih besar daripada nilai $(t)$ yang diperoleh dari tabel distribusi $\left(t_{\text {tabel }}\right)=1,980$ dengan taraf signifikansi sebesar $5 \%\left(t_{\text {hitung }}>t_{\text {tabel }}\right)=(3,250>1,980)$ membuktikan bahwa terdapat pengaruh yang positif sebesar 3,250 antara manajemen kelas terhadap keaktifan belajar peserta didik di MTs Madani Alauddin Kabupaten Gowa.

\section{SIMPULAN}

Berdasarkan uraian tentang manajemen kelas terhadap keaktifan belajar peserta didik di MTs Madani Alauddin Kabupaten Gowa maka dapat disimpulkan bahwa:

1. Manajemen kelas di MTs Madani Alauddin Kabupaten Gowa berada pada kategori sedang, hal tersebut diperoleh, dari hasil analisis data 84 peserta didik dengan rincian terhadap 18 atau 21,43\% peserta didik yang berada dalam kategori tinggi, 56 atau 66,67\% peserta didik yang berada dalam kategori sedang, 10 atau 11,90\% peserta didik yang berada dalam kategori rendah. 
2. Keaktifan belajar peserta didik di MTs Madani Alauddin Kabupaten Gowa berada pada kategori sedang, hal tersebut diperoleh dari hasil análisis data 84 peserta didik dengan rincian terdapat 12 atau 14,28\% peserta didik yang berada dalam kategori tinggi, 57 atau $67,86 \%$ peserta didik berada dalam kategori sedang, 15 atau $17,86 \%$ peserta didik berada dalam kategori rendah.

3. Berdasarkan hasil statistik inferensial pengujuan hipótesis yang menunjukkan bahwa nilai $(t)$ yang diperoleh dari hasil perhitungan ( $\left.t_{\text {hitung }}\right)=3,250$ lebih besar daripada nilai $(t)$ yang diperoleh dari tabel distribusi $\left(t_{\text {tabel }}\right)=1,980$, thitung $\geq$ ttabel $=$ $3,250 \geq 1,980$, hal tersebut menunjukkan bahwa terdapat pengaruh yang signifikan manajemen kelas terhadap keaktifan belajar di MTs Madani Alauddin Kabupaten Gowa.

\section{DAFTAR PUSTAKA}

Afiif, A., \& Ridwan, I. (2016). “Pengaruh Implementasi Manajemen Kelas terhadap Perilaku Belajar Mahasiswa pada Jurusan Manajemen Pendidikan Islam Fakultas Tarbiyah dan Keguruan UIN Alauddin Makassar", Lentera Pendidikan Vol. 19, No. 2: h. 131-145.

Arikunto, S. (2002). Prosedur Penelitian Suatu Pendekatan Praktek. Jakarta: Rineka Cipta.

Danim, S. (2002). Inovasi Pendidikan, Cet. I; Bandung: Pustaka Setia.

Djamarah, S. B., \& Zain, A. (2010). Strategi Belajar Mengajar, Cet. IV; Jakarta: Rineka Cipta.

Djamarah, S. B. (2005). Guru dan Anak Didik dalam Interaksi Edukatif suatu Pendekatan Teoritis Psikologis. Jakarta: Rineka Cipta.

Emzir. (2013). Metodologi Penelitian Pendidikan: Kuantitatif dan Kualitatif, Cet. VII; Jakarta: RajaGrafindo Persada.

Getteng, A. R. (2014). Menuju Guru Profesional dan Beretika, Cet. IX; Yogyakarta: Grha Guru.

Gulo, W. (2002). Strategi Belajar Mengajar. Jakarta: PT. Grasimdo Widiasarana.

Hamalik, O. (2001). Proses Belajar Mengajar. Jakarta: Bumi Aksara.

Hasbullah. (2012). Dasar-dasar Ilmu Pendidikan, Cet. X; Jakarta: RajaGrafindo Persada.

Ismail, M. I. (2015). Metodologi Penelitian Pendidikan. Makassar: Alauddin University Press.

Muhaimin. (2009). Manajemen Pendidikan. Jakarta: Kencana.

Priansa, D. Juni. (2015). Manajemen Peserta Didik dan Model Pembelajaran, Cet. I; Bandung: Alfabeta.

Pusat Bahasa Departemen Pendidikan Nasional. (2005). Kamus Besar Bahasa Indonesia, Cet. III; Jakarta: Balai Pustaka.

Sardiman. (2014). Interaksi dan Motivasi Belajar Mengajar, Cet. XXII; Jakarta: RajaGrafindo Persada.

Sugiyono. (2015). Metode Penelitian Pendidikan: Pendekatan Kuantitatif \& Kualitatif, Bandung: Alfabeta.

Sulistyani, S. N. (2012). "Peningkatan Keaktifan Belajar Siswa dengan Penerapan Metode Guided Note Taking pada Mata Diklat Memilih Bahan Baku Busana di SMKN 4 Yogyakarta", Studia Islamika 27, No. 3: h. 137-152.

Supranto, J. (2008). Statistik Teori dan Aplikasi. Jakarta: Erlangga.

Usman, M. U. (2009). Menjadi Guru Profesional. Bandung: PT. Remaja Rosdakarya. 
Wiyani, N. A. (2013). Manajemen Kelas, Cet.I; Yogyakarta: Ar-Ruzz Media.

Yamin, M., \& Maisah. (2009). Manajemen Pembelajaran Kelas Strategi Meningkatkan Mutu Pendidikan, Jakarta: Gaung Persada Press. 